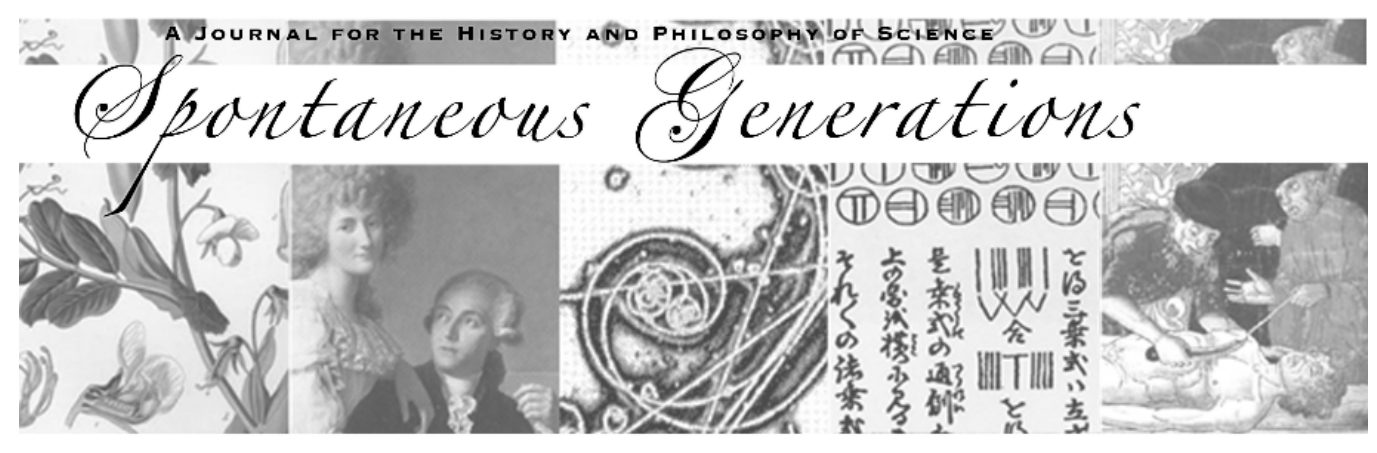

The political economy of technoscience: An emerging research agenda

Author(s): Kean Birch

Source: Spontaneous Generations: A Journal for the History and Philosophy of Science, Vol. 7, No. 1 (2013) 49-61.

Published by: The University of Toronto

DOI: 10.4245/sponge.v7i1.19556

\author{
EDITORIAL OFFICES \\ Institute for the History and Philosophy of Science and Technology \\ Room 316 Victoria College, 91 Charles Street West \\ Toronto, Ontario, Canada M5S 1K7 \\ hapsat.society@utoronto.ca
}

Published online at jps.library.utoronto.ca/index.php/SpontaneousGenerations ISSN 19130465

Founded in 2006, Spontaneous Generations is an online academic journal published by graduate students at the Institute for the History and Philosophy of Science and Technology, University of Toronto. There is no subscription or membership fee. Spontaneous Generations provides immediate open access to its content on the principle that making research freely available to the public supports a greater global exchange of knowledge. 


\title{
The political economy of technoscience
}

\section{An emerging research agenda*}

\author{
Kean Birch ${ }^{\dagger}$
}

\begin{abstract}
This short essay presents the case for a renewed research agenda in STS focused on the political economy of technoscience. This research agenda is based on the claim that STS needs to take account of contemporary economic and financial processes and how they shape and are shaped by technoscience. This necessitates understanding how these processes might impact on science, technology and innovation, rather than turning an STS gaze on the economy.
\end{abstract}

\section{INTRODUCTION}

Economics and science are intrinsically entwined domains of life and research, whether we like to think so or not. It can be uncomfortable to acknowledge that pharmaceutical research is tied to brutish "economic" calculations of returns on investment and not just the "moral economy" of quality of life or ethical responsibility. Yet these calculations are what people do on a daily basis in life science companies, in investment firms, and in stockbrokerages. These dismal decisions-to misappropriate Thomas Carlyle's description of economics-are necessary objects of investigation for anyone interested in social, historical or philosophical studies of science and technology, as this special issue highlights. Hence the economics of science must go beyond the narrow application of economics to science and technology, or what many scholars now call technoscience. It has to address the political economy of technoscience; by this I mean the ways that the economy is ethically, socially and politically organized and configured and how this shapes technoscience and is constituted by technoscience in turn.

Political economy is often conflated with specific forms of political-economic analysis like Marxism; it is not my intent to make that conflation here. In this short article I want to think about how social, historical and philosophical studies of science and technology-or science and technology studies (STS) for short-can engage with contemporary political economy. Classical political

* Received 15 March 2013. Accepted 16 August 2013.

$\dagger$ Kean Birch is an Assistant Professor in the Business and Society program in the Department of Social Science at York University. He is a member of the graduate faculty of Graduate Program in STS. 
economy concerns the social and political context in which the production, consumption and distribution of goods, services and wealth happens. By contemporary political economy I mean to include the growing literature on subjectivities, moral discourses, institutions, knowledge and innovation dynamics, and natural ecologies that constitute and are constituted by the social and political context of economic activity (see Hudson 2008; Robbins et al. 2010; Mirowski 2011; Tyfield 2012a, 2012b, 2012c; Mazzucato 2013). What is important to note is that political economy rejects the underlying assumptions of neoclassical economics and economic models, such as fixed and rational self-interest, static preferences and utility-maximizing behaviour (Mirowski 2011). In this sense it is important, as one referee pointed out to me, not to conflate the "economy"-itself a fairly recent epistemological construction according to Mitchell (2011)-with "economics."

The recent "economic turn" in STS has involved an examination of "economics," "economy" and how technoscience is implicated in both the pursuit of economic knowledge and the construction of economies (e.g. Callon 1998; Pinch and Swedberg 2008; MacKenzie 2009). What this economic turn has not done so well, however, is examine how economics, as a discipline and disciplinary tool, and "economic" activities shape or co-produce technoscience; or in other words, what political economy-the study of social and political context-can tell us about the promotion and development of technoscience. There are obviously exceptions to my claims including the work of people like Philip Mirowski (2011), David Tyfield (2012a; 2012b; 2012c), and others (e.g. Mirowski and Nik-Khah 2008; Lave et al. 2010; Thorpe and Gregory 2010; Birch 2012; Courtney and Abraham 2013; Birch and Tyfield 2013). Moreover, there are broader fields like the economics of science (see Belladonne 2012) and innovation studies (see Fagerberg and Verspagen 2009) which have always focused on these issues, although from specific analytical perspectives. What I want to do in the rest of the article is update the STS audience on some emerging research and research agendas that are rejuvenating the political-economic study of technoscience.

\section{Starting Points}

It is important to acknowledge that STS scholars have engaged with political economy over the years, and that what I am outlining as an emerging agenda is not necessarily a radically new perspective. People like David Noble (1984) and Edward Yoxen (1984), for example, produced materialist (i.e. Marxist) analyses of technologies like machine tools and biotechnology in the 1980s. In the same era, others like Hughes (1983) produced detailed work on the emergence of socio-technical and economic systems such as energy infrastructure, a field which is opening up again with work on sustainable transitions (e.g. Monstadt 2009; Lawhon and Murphy 2012; Truffer and Coenen 2012). And, as mentioned already, there is a whole field dedicated to studying innovation from an 
evolutionary and Schumpeterian perspective (see Fagerberg and Verspagen 2009 for a review) as well the field of economics of science itself (see Belladonne 2012). It seems though that STS scholars sometimes forget the history of their own discipline.

To illustrate what I mean, I refer to the recent revival of interest in Marxist political economy, as shown by the emergence of concepts like "biovalue" (Waldby 2000) and "biocapital” (e.g. Helmreich 2008) in (mainly) anthropological studies of technoscience. One apt example is a recent edited collection entitled Lively Capital which covers a range of topics from this perspective (Rajan 2012). However, what this revival of (one form of) political economy merely indicates is the stagnant waters in which much STS thinking is slowly bubbling: when it comes to political economy, we frequently find STS stuck in the mud of the past. Specifically, it is stuck in the nineteenth century, with a return to Marx evident in these hybrid concepts. Not that there is anything wrong with Marx, of course; it is just that it is important to update our understanding of political economy by exploring contemporary political-economic processes, practices and contexts-which I will come back to shortly-rather than returning to those more appropriate to a different age.

It is a rare sight to find STS scholars engaging in any serious way with contemporary political economy; that is, examining how different political-economic processes, practices and contexts inform technoscience. One example of this deficit will have to suffice here. It is puzzling that STS scholars have largely failed to engage with neoliberalism as either a particular process involving the commercialization of technoscience, or a set of market-based practices, or the social and political context of technoscientific change. While there are notable exceptions to this, which I will come back to shortly, the fact that Social Studies of Science (SSS)-one of the premier journals in STS-only has 29 articles referencing the word "neoliberal' is tantamount to burrowing our heads in the sand. ${ }^{1}$ STS has totally dropped the ball on this one. A possible reason for this neglect may be that dominant STS approaches can fit very comfortably within neoliberal tenets; for example, Chris McClellan (1996) argues that actor-network theory (ANT) appropriates the language of neoclassical economics and the political justification of market-based perspectives. In particular, McClellan makes the important point that ANT mirrors neoclassical assumptions that "social structure is the result of individuals pursuing personal interest by linking up with others in a reciprocal exploitation of each other"s activity for the satisfaction of the personal interest of each agent involved" (p.199). In this ANT framework, science is turned into a "marketplace for ideas"

1 Science, Technology and Human Values only comes out a little better with 42 references, while Science and Public Policy only has 16 and Public Understanding of Science only has 7 references. For full disclosure, Science as Culture, on which I am an Associate Editor, also only has 29 references to "neoliberal." 
with the result, according to Mirowski that "it seems neoliberalism had taken root in the most avant-garde precincts of science studies [i.e. ANT], gussied up with the seemingly non-economic terminology of actants, rhizomes, and parliaments of things" $(2011,66)$.

What is evident is that the global financial crisis has opened up not only interest in neoliberalism in STS-for example, 24 of the 29 articles referencing neoliberalism in SSS have been published since 2008-but also the political space to even discuss it as a suitable topic. Other than neoliberalism, STS scholars have also ignored other areas of contemporary political economy such as financialization (not one reference in SSS) and corporate governance (one mention), illustrating the extent to which political economy has been evacuated from STS. I chose those two examples for the following reasons: first, financialization is not only implicated in the global financial crisis and the lead-up to the current mess we are in but also in changing innovation policies and strategies (see Serfati 2008; Andersson et al. 2010; Lazonick and Tulum 2011), yet it has been almost totally ignored in STS; and second, corporate governance is increasingly important as more and more economic activity-about half-is undertaken inside business organizations rather than in markets (Hodgson 2005). Again, the failure to consider such corporate configurations is a major gap in STS, with some exceptions (e.g. Vallas and Kleinman 2008). Despite these gaps in STS, an emerging research agenda has gradually surfaced. There are examples I can point to, as the title of my article should indicate, but they are not commonplace even if there is increasing interest in such topics. For example, there are now a number of scholars engaging in these debates, especially the relationship between neoliberalism and technoscience (e.g. Birch 2006; Berman 2008; Kinchy et al. 2008; Lave et al. 2010; Biddle 2011; Mirowski 2011; Moore et al. 2011; Tyfield 2012c).

This emerging research agenda in STS, small as it is right now, offers the STS discipline an important opportunity to re-engage with political economy. Not only that, it is our responsibility as STS scholars to re-engage in order to understand how technoscience has been and is being shaped by contemporary political and economic knowledge claims about things like market efficiency, consumer welfare, and returns on investment. However, in order to do this we need to understand what orthodox and heterodox economists and political economists are writing about (i.e. epistemic claims), how they are theorizing (i.e. moral claims), and what they are promoting as contemporary policy proposals (i.e. political claims). These diverse claims are incredibly powerful, providing visions and narratives that drive research and innovation policies (see Felt et al. 2007) as well as the co-production of scientific and (political-) economic orders (see Levidow et al. 2012a; 2012b). What I want to do now is highlight some key aspects of this emerging research agenda and identify where I think we need to do more work. 


\section{An Emerging Research Agenda}

I want to start the discussion of this emerging research agenda by suggesting that we need to look squarely in the face of the political-economic transformations our societies have faced over the last few decades as specific economic epistemic claims (i.e. neoliberalism) have dominated ethical, political and social agendas, and shaped technoscientific pathways. This is necessary in order to find ways to challenge the assumptions-of neoclassical economics in particular-underpinning our social, political and economic orders that militate against the (radical and systemic) technoscientific transitions required to save our societies from the combined global crises of ecological and economic ruin. If STS scholars do not take up this challenge then it is left to others, like neoclassical economists, who are likely to promote discredited, although still powerful, epistemic claims that are embedded in numerous technologies and embodied by numerous policy-makers (see Mirowski 2010, 2011, 2013). Ultimately, what this means for STS scholars is that there is a need to engage more visibly and deeply with concepts, theories and approaches drawn from across political economy. The research agenda I'm discussing here has emerged from different analytical origins, providing something for everyone should they choose to look. It is to this diversity that I now turn.

First, there are the fields close to STS-"cousin" disciplines-like innovation studies (see Fagerberg and Verspagen 2009 for a review). This field has produced some very insightful analyzes of research and innovation process and policies, including studies by many scholars at the department of Science and Technology Policy Research, University of Sussex, working on the biotechnology sector (e.g. Nightingale and Martin 2004; Hopkins et al. 2007) and other areas (e.g. Mazzucato 2013). As a field, innovation studies illustrates an already mature research agenda, but one ripe for further STS contributions and cross-overs, especially since innovation studies has thus far been somewhat dominated by evolutionary and Schumpeterian conceptions of socio-technical change. Of particular relevance to future STS scholarship is the emerging literature on sustainable transitions, which focuses on socio-technical systems and socio-technical regimes (e.g. Geels and Schot 2007; Shove and Walker 2007; Lawhon and Murphy 2012; Truffer and Coenen 2012). What the theorization and analysis of sustainable transitions has done is open up our understanding of how socio-technical systems and institutions both encourage transitions and lock societies into existing technoscientific pathways. For example, an important, and still emerging, area of interest is infrastructure-or "infra-systems"-including the planning, design and development of infrastructure and what it means for supporting or limiting sustainable transitions (e.g. Frantzeskaki and Loorbach 2010; Birch and Wudrich 2013; Bolton and Foxon 2013).

Second, STS already benefits from the cross-fertilization of ideas in closely related disciplines like sociology and anthropology. However, there is plenty 
of political-economic research in these subjects that is not currently very influential or has been entangled with the "economic turn" in STS (e.g. Callon 1998; MacKenzie 2009). There are several insightful analyses of economic, financial and evaluative processes in both anthropology and sociology that have contributed to the emerging political economy agenda in STS. In anthropology, these include, but are not limited to, the following: (a) the work of Karl Polanyi (2001[1944]) on fictitious commodities, which is particularly relevant to the commercialization of technoscience behind intellectual property rights (e.g. Tyfield 2008) and the creation of new markets like climate trading (e.g. Lohmann 2010) or weather derivatives (e.g. Randalls 2010); (b) the concept of "virtualism" arising from the work of James Carrier and Daniel Miller (1998), which has informed my own work on the bio-economy (Birch 2007) as well as that of others (e.g. Ponte 2009). There is also work by David Graeber (2001) on value, in which he emphasizes the need to think about value in terms of action, and artefacts as processes rather than stable or static things; and the work by Karen Ho (2009) on organizational cultures in financial firms and their implications for how businesses are run and how employees act. These examples offer STS scholars several possibilities for engaging with a range of new issues, whether in terms of thinking about technoscience in terms of economic process or how economic cultures (e.g. finance) influence research and development.

In sociology there are several areas that might be of interest to STS. Although recent and ongoing research on socio-technical imaginaries has proved influential in STS, especially the work of Sheila Jasanoff (2004) and collaborators (e.g. Kim and Jasanoff 2009) on the co-production of technoscientific and political orders, it is missing one critical element; namely, a proper consideration of the economics of science (Tyfield 20012c). The work of Bob Jessop (2010) on economic imaginaries represents a useful complement here, as illustrated by my own work with colleagues (e.g. Birch et al. 2010; Levidow et al. 2012a; Birch and Ponte 2013). We need to understand these economic imaginaries, how they are constructed, and how they relate to specific forms of political legitimation-e.g. social democratic, neoliberal, statist, etc. Sociology might also contribute more when it comes to economic sociology, going beyond the "economic turn" in STS. Sociologists like Patrik Aspers (2007; 2009), for example, provide an interesting analysis of different types of markets and how they are constituted by different forms of social order and social structure. These differences obviously have different implications for research and innovation (see Birch and Tyfied 2013). Aspers' work dovetails nicely with STS conceptions of technological expectations (e.g. Brown and Michael 2003; Borup et al. 2006) since such expectations add another dimension to market exchange. Another relevant sociological angle is the research on global commodity chains and/or value chains (GCC/GVC) which has emerged from the work of Gary Gereffi (1996) and others (e.g. Gibbon 
and Ponte 2008). ${ }^{2}$ There are clear conceptual and methodological resemblances between GCC/GVC and STS approaches, especially with the former's call to "follow the thing" in analysis. Moreover, the emphasis in GCC/GVC approaches on the configuration and governance of commodity or value chains provides a useful lens from which to explore not only artefacts and other technoscientific developments, but also epistemic, regulatory and economic practices (e.g. Birch and Cumbers 2010).

Third, there is a wealth of political-economic research in other disciplines of the social sciences. What I want to do here is to provide a flavour of this research rather than continue going through each field in turn. First, in human geography there is a growing interest in materialities of nature and the environment (e.g. Castree 2008a; 2008b), as well as technologies and artefacts (e.g. Truffer 2008). Much of the former builds on work in political ecology by focusing on the neoliberalization of nature and the environment through the introduction of market-based processes and mechanisms (see Bakker 2011). One particularly important part of this work on "neoliberal natures"-as it has come to be known-is the way that it problematizes the notion that humans are in charge of nature; it highlights the material recalcitrance of nature as it is incorporated into capitalist and industrial processes and mechanisms (e.g. Boyd et al. 2001). In this sense it fits neatly into issues of material agency that have dominated thinking in STS for some time. Second, there is a range of work in political science that could be relevant to a renewed research agenda in the political economy of technoscience. The field of international political economy (IPE), for example, has exploded in the last few years, well before the global financial crisis. Much of this research could be related to STS and is perhaps too broad to be considered adequately here. One suggestion, however, is the need to look at the technoscience of things like public, corporate and household debt or tax evasion through transfer pricing of intellectual property. A much clearer example of the close fit between STS and political science is the work of Timothy Mitchell $(2005 ; 2011)$, whose research on the construction of markets and "carbon democracy" integrates ideas and approaches from both fields (see Birch and Calvert forthcoming). As with human geography, Mitchell integrates issues of materiality in his analysis, illustrating the need to think beyond socio-technical systems to the social and material dynamics covering the social, technical and environmental aspects in STS analysis. Here the concept of socio-material systems might be a useful addition to STS scholarship, incorporating the social and technoscientific with the materiality of a recalcitrant "nature."

Finally, there is economics itself. As contested knowledge, economics entails contested values-particularly in light of its very public failure to predict or ameliorate the global financial crisis (Mirowski 2013). Whether or not we agree

2 See website: http://www.globalvaluechains.org/concepts.html 
with the founding assumptions of methodological individualism or rational self-interest-which I assume many people in STS would not, but see my earlier comments about ANT-the emerging agenda in the political economy of technoscience has confronted these assumptions head-on (see above). However, what I want to highlight here are examples of where STS might fruitfully engage with economists. There are at least three areas which have already proved influential or might prove influential in the future. First, there is existing work by institutional and evolutionary economists that I mentioned above in relation to their influence on innovation studies. The recent work of scholars like Mariana Mazzucato (2013) on the (positive) role of the state in promoting innovation helps to illustrate how economics might be enrolled in challenging dominant "myths" about the benefits of (free) markets. Second, there are other areas where STS interests might overlap with key topics in economics. First, over the last few decades financial economists have studied corporate governance and corporate finance, transforming the economics discipline as well as the world (see Dobbin and Jung 2010). The reason to look at corporate governance is that technoscience is increasingly a private sector activity (Mirwoski 2011), while economic activities and practices are now largely undertaken within business organizations rather than in (free) markets (Hodgson 2005). However, corporate governance raises questions about the organization of research and development (R\&D) since it is increasingly dependent upon forms of private oversight and commodified governance that are bound up with relationships between management and investors (Lazonick and Tulum 2011). What this means is that it would be useful to understand how particular economic knowledges, like corporate finance, inform technoscience; for example, what are the implications of shareholder primacy for research and development decisions? How do investors and shareholders calculate and judge the value of R\&D? What does this mean for wider science and innovation agendas and policies? These are all issues in need of investigation, yet they seem peripheral to much STS scholarship right now. Second, there have been major changes in accounting and valuation processes over the last few years. Increasingly, intangible assets like software and data, intellectual property, human capital, etc. have come to dominate the evaluation and calculation of value (Serfati 2008; Pagano and Rossi 2009). This accounting of intangible assets seems more than relevant to STS scholarship, considering that it deals with the focus of much STS research.

\section{Conclusion}

This short article can only provide the bare bones of the emerging research agenda around the political economy of technoscience. I have mentioned some of the areas where I think it would be worthwhile to pursue further STS work. By no means is this an exhaustive or definitive list of topics-it is very 
much meant to be illustrative. What is important for STS is to continue to engage with other social science disciplines on this topic. What I want to emphasize in this conclusion is that STS scholars need to tackle (or tangle with) a range of important political-economic processes that are very much implicated in the development and constitution of technoscience. Some I have already mentioned, like financialization and neoliberalization, but others are also worthy of attention as well. These include privatization of technoscientific services (e.g. forensic services in the UK), commodification and commercialization of everything (e.g. climate credits), and marketization of R\&D (e.g. impact agenda in the UK). It is important to note that not everything involves the extension or intensification of markets, or particular forms of economistic thinking. There are plenty of examples of opposite trends worth researching, examples of which would include de-commercialization or nationalization of technoscience as well as the rise of open science and open source forms of property rights (e.g. Hope 2008; Dove et al. 2012). What is meant to be evident from this brief trawl of various fields of research is the wealth of areas of emerging and potential research open to those interested in understanding the political economy of technoscience, and their insights into how we might contribute not only to a renewal of this area of research, but also to a critical engagement with the economic context in which science, technology and innovation happen (see Galis and Hansson 2012).

\author{
KeAN BIRCH \\ Department of Social Science \\ York University, Toronto \\ kean@yorku.ca
}

\title{
References
}

Andersson, T., Gleadle, P., Haslam, C. and Tsitsianis, N. 2010. Bio-pharma: A financialized business model. Critical Perspectives on Accounting 21: 631-641.

Aspers, P. 2007. Theory, reality, and performativity in markets. American Journal of Economics and Sociology 66 (2): 379-98.

Aspers, P. 2009. Knowledge and valuation in markets. Theory and Society 38 (2): 111-131.

Bakker, K. 2010. The limits of "neoliberal natures": Debating green neoliberalism. Progress in Human Geography 34(6): 715-735.

Ballandonne, M. 2012. New economics of science, economics of scientific knowledge and sociology of science: the case of Paul David. Journal of Economic Methodology 19(4): 391-406.

Berman, E.P. 2008. The politics of patent law and its material effects: The changing relationship between universities and the marketplace. In Living in a Material World, eds. T. Pinch and R. Swedberg, 191-213. Cambridge MA: MIT Press. 
Birch, K. 2006. The neoliberal underpinnings of the bioeconomy: The ideological discourses and practices of economic competitiveness. Genomics, Society and Policy 2(3): 1-15.

Birch, K. 2012. Knowledge, place and power: Geographies of value in the bioeconomy. New Genetics and Society 31(2): 183-201.

Birch, K. and Calvert, K. Forthcoming. Rethinking 'drop-in' biofuels: On the political materialities of bioenergy. Science and Technology Studies.

Birch, K. and Cumbers, A. 2010. Knowledge, space and economic governance: The implications of knowledge-based commodity chains for less-favoured regions. Environment and Planning A 42(11): 2581-2601.

Birch, K. and Tyfield, D. 2013. Theorizing the bioeconomy: Biovalue, biocapital, bioeconomics or ...what? Science, Technology and Human Values 38(3): 299-327.

Birch, K. and Wudrich, D. 2013. Climate change, sustainable infrastructure and the challenge facing engineers. Engineering Dimensions (Sept/Oct): 46-48.

Bolton, R. and Foxon, T. 2013. Urban infrastructure dynamics: market regulation and the shaping of district energy in UK cities. Environment and Planning A, doi:10.1068/a45575

Borup, M., Brown, N., Konrad, K. and Van Lente, H. 2006. The sociology of expectations in science and technology. Technology Analysis and Strategic Management 18 (3/4): 285-98.

Boyd, W., Prudham, W.S. and Schurman, R. 2001. Industrial dynamics and the problem of nature. Society and Natural Resources 14(7): 555-570.

Brown, N. and Michael, M. 2003. A sociology of expectations: Retrospecting prospects and prospecting retrospects. Technology Analysis and Strategic Management 15(1): 3-18

Carrier, J. and Miller, D., eds. 1998. Virtualism: A New Political Economy. Oxford: Berg.

Castree, N. 2008a. Neoliberalising nature: The logics of deregulation and reregulation. Environment and Planning A 40: 131-152.

Castree, N. 2008b. Neoliberalising nature: Processes, effects, and evaluations. Environment and Planning A 40: 153-173.

Davis, C. and Abraham, J. 2013. Unhealthy Pharmaceutical Regulation: Innovation, Politics and Promissory Science. London: Palgrave.

Dobbin, F, and Jung, J. 2010. The misapplication of Mr. Michael Jensen: How agency theory brought down the economy and why it might happen again. In Markets on Trial: The Economic Sociology of the U.S. Financial Crisis, eds. M. Lounsbury and P. Hirsch, 29-64. Bingley: Emerald.

Dove, E., Ozdemir, C. and Joly, J. 2012. Harnessing omics sciences, population databases, and open innovation models for theranostics-guided drug discovery and development. Drug Development Research 73: 439-446.

Fagerberg, J. and Verspagen, B. 2009. Innovation studies-The emerging structure of a new scientific field. Research Policy 38: 218-233.

Felt, U., rapporteur. 2007. Science and governance: Taking European knowledge society seriously. Brussels: European Commission, EUR 22700. 
Frantzeskaki, N. and Loorbach, D. 2010. Towards governing infrasystem transitions: Reinforcing lock-in or facilitating change? Technological Forecasting \& Social Change 77: 1292-1301.

Galis, V. and Hansson, A. 2012. Partisan scholarship in technoscientific controversies: Reflections on research experience. Science as Culture 21: 335-364.

Geels, F. and Schot, J. 2007. Typology of sociotechnical transition pathways. Research Policy, 36(3): 399-417.

Gereffi, G. 1996. Global commodity chains: new forms of coordination and control among nations and firms in international industries. Competition and Change 1: 427-439.

Gibbon, P. and Ponte, S. 2008. Global value chains: From governance to governmentality? Economy and Society 37(3): 365-392.

Graeber, D. 2001. Towards an Anthropological Theory of Value. London: Palgrave.

Helmreich, S. 2008. Species of biocapital. Science as Culture 17 (4): 463-78.

Ho, K. 2009. Liquidated: An Ethnography of Wall Street. Durham: Duke University Press.

Hodgson, G. 2005. Knowledge at work: Some neoliberal anachronisms. Review of Social Economy 63(4): 547-565.

Hope, J. 2008. Biobazaar: The Open Source Revolution and Biotechnology. Cambridge, MA: Harvard University Press.

Hopkins, M., Martin, P., Nightingale, P., Kraft, A. and Mahdi, S. 2007. The myth of the biotech revolution: an assessment of technological, clinical and organisational change. Research Policy 36(4): 566-589.

Hudson, R. 2008. Cultural political economy meets global production networks: a productive meeting? Journal of Economic Geography 8: 421-440.

Hughes, T. 1983. Networks of Power: Electrification in Western Society, 1880-1930. Baltimore: Johns Hopkins University Press.

Jasanoff, S., ed. 2004. States of Knowledge: The Co-Production of Science and Social Order. London: Routledge.

Kinchy, A., Kleinman, D. and Auty, R. 2008. Against free markets, against science? Regulating the socio-economic effects of biotechnology. Rural Sociology 73(2): 147-179.

Lave, R., Mirowski, P. and Randalls, S. 2010. Introduction: STS and neoliberal science. Social Studies of Science 40(5): 659-675.

Lawhon, M. and Murphy, J. 2012. Socio-technical regimes and sustainability transitions: Insights from political ecology. Progress in Human Geography 36(3): 354-378.

Lazonick, W. and Tulum, O. 2011. US biopharmaceutical finance and the sustainability of the biotech business model. Research Policy 40(9): 1170-1189.

Levidow, L., Birch, K. and Papaioannou, T. 2012a. EU agri-innovation policy: Two contending visions of the knowledge-based bio-economy. Critical Policy Studies 6(1): 40-66.

Levidow, L., Papaioannou, T. and Birch, K. 2012b. Neoliberalising technoscience and environment: EU policy for competitive, sustainable biofuels. In Neoliberalism and Technoscience: Critical Assessments, eds. L. Pellizzoni and M. Ylönen, 159-186. Farnham: Ashgate Publishers. 
Lohmann, L. 2010. Neoliberalism and the calculable world: The rise of carbon trading. In The Rise and Fall of Neoliberalism: The Collapse of an Economic Order?, eds. K. Birch and V. Mykhnenko, 77-93. London, Zed Books.

MacKenzie, D. 2009. Material Markets: How Economic Agents are Constructed. Oxford: Oxford University Press.

Mirowksi, P. 2010. The Great Mortification: Economists' responses to the Crisis of 2007-(and counting). The Hedgehog Review 12(2): 28-41.

Mirowski, P. 2011. ScienceMart. Cambridge, MA: Harvard University Press.

Mirowski, P. 2013. Never Let a Serious Crisis Go to Waste. London: Verso.

Mirowski, P. and Nik-Khah, E. 2008. Command performance: Exploring what STS thinks it takes to build a market. In Living in a Material World, eds. T. Pinch and R. Swedberg, 89-128. Cambridge MA: MIT Press.

Mitchell, T. 2005. The work of economics: how a discipline makes its world. European Journal of Sociology 46: 297-320.

Mitchell, T. 2011. Carbon Democracy: Political Power in the Age of Oil. London: Verso.

Monstadt, J. 2009 Conceptualizing the political ecology of urban infrastructures: insights from technology and urban studies. Environment and Planning A 41: 1924-1942.

Moore, K., Kleinman, D., Hess, D. and Frickel, S. 2011. Science and neoliberal globalization: A political sociological approach. Theory and Society 40: 505-532.

Nightingale, P. and Martin, P. 2004. The myth of the biotech revolution. Trends in Biotechnology 22(11): 564-569.

Noble, D. 1984. Forces of Production; A Social History of Industrial Automation. New York: Knopf.

Pagano, U. and Rossi, A. 2009. The crash of the knowledge economy. Cambridge Journal of Economics 33: 665-683.

Pinch, T. and Swedberg, R., eds. 2008. Living in a Material World: Economic Sociology meets Science and Technology Studies. Cambridge MA: MIT Press.

Polanyi, K. 2001 [1944]. The Great Transformation. Boston: Beacon.

Ponte, S. 2009. From fishery to fork: Food safety and sustainability in the 'virtual' knowledge-based bio-economy (KBBE). Science as Culture 18(4): 483-495.

Rajan, K. S. 2006. Biocapital. Durham: Duke University Press.

Randalls, S. 2010. Weather profits: Weather derivatives and the commercialization of meteorology. Social Studies of Science 40(5): 705-730.

Serfati, C. 2008. Financial dimensions of transnational corporations, global value chain and technological innovation. Journal of Innovation Economics 2: 35-61.

Shove, E. and Walker, G. 2007. CAUTION! Transitions ahead: Politics, practice, and sustainable transition management. Environment and Planning A 39: 471-476.

Thorpe, C. and Gregory, J. 2010. Producing the Post-Fordist public: The political economy of public engagement with science. Science as Culture 19(3): 273-302.

Truffer, B. 2008. Society, technology, and region: Contributions from the social study of technology to economic geography. Environment and Planning A 40: 966-985.

Truffer, B. and Coenen, L. 2012. Environmental innovation and sustainability transitions in regional studies. Regional Studies 46(1): 1-21.

Tyfield, D. 2008. Enabling TRIPs: The Pharma-Biotech-University Patent Coalition. Review of International Political Economy 15(4): 535-566. 
Tyfield, D. 2012a. The Economics of Science: A Critical Realist Overview (Vol.1) Illustrations and Philosophical Preliminaries. Abingdon \& New York: Routledge.

Tyfield, D. 2012b. The Economics of Science: A Critical Realist Overview (Vol.2) - Towards a Synthesis of Political Economy and Science \& Technology Studies. Abingdon \& New York: Routledge.

Tyfield, D. 2012c. A cultural political economy of research and innovation in an age of crisis. Minerva 50: 149-167.

Vallas, S. and Kleinman, D. 2008. Contradiction, Convergence, and the Knowledge Economy: The Co-Evolution of Academic and Commercial Biotechnology. Socio-Economic Review 6(2): 283-311.

Waldby, C. 2000. The Visible Human Project. London: Routledge.

Yoxen, E. 1984. The Gene Business: Who Should Control Biotechnology? Oxford: Oxford University Press. 